\title{
Pemilu Legislatif DKI Jakarta dalam Paparan Media Daring: Analisis Isi Pemberitaan Caleg Dapil I,II,dan III Jakarta pada Pemilu 2019
}

\author{
Titin Setiawati \\ Institut Bisnis Nusantara Jakarta \\ titin.affandhi@gmail.com
}

\begin{abstract}
After the Reformation era, started in 2014, the system for general elections was changed by open proportional system. The legislative candidates with the most votes will be elected as members of parliament, and for the second time the system was repeated in April 2019. In media sector, online media utilization has gained widespread attention during the last election. Online media is often used for election campaigns; especially by parties and candidates who have an interest in voting for the constituents. This research using the media monitoring method for online media from January to February 2019 for Jakarta I, II, and III Election Areas. The results of the study show that the news shows more political events in general. Most of the news is not directed at parties or candidates so it is less effective in introducing parties and candidates. News in online media is also less capable of being a positive learning tool for politics for the community
\end{abstract}

Keyword : content analysis, online media, election, parliament election

\begin{abstract}
Abstrak. Selepas reformasi, mulai 2014 sistem penyelenggaraan pemilu menggunakan sistem proporsional terbuka. Calon legislatif dengan suara terbanyaklah yang akan terpilih menjadi anggota parlemen, dan untuk kedua kalinya sistem tersebut berlaku pada pemilu April 2019. Pada aras media, utilisasi media daring (online) memperoleh perhatian luas selama pemilu terakhir. Bagi para kontestan pemilu, media daring kerap digunakan untuk kampanye pemilu; terutama oleh partai dan caleg yang berkepentingan memperebutkan suara konstituen. Penelitian ini menggunakan analisis isi untuk berita daring pada Januari-Februari 2019 untuk Daerah Pemilihan (Dapil) I,II,dan III Daerah Khusus Ibukota Jakarta. Hasil penelitian menunjukkan bahwa pemberitaan lebih banyak menampilkan peristiwa politik secara umum. Sebagian besar berita bukan mengarah kepada partai atau caleg sehingga kurang efektif sebagai media pengenalan partai dan caleg. Berita di media daring juga kurang mampu menjadi sarana pembelajaran positif tentang politik bagi masyarakat.
\end{abstract}

Kata kunci: Analisis isi, media daring, pemilihan umum, pemilu legislatif 


\section{Pendahuluan}

Pemilihan umum merupakan cara warga negara untuk memberikan suara dan memilih wakilnya. Pasca-kemerdekaan Indonesia, untuk pertama kali, pemilihan umum diselenggarakan pada 1955 ketika era pemerintahan Presiden Sukarno. Pemilihan umum diselenggarakan untuk memilih anggota DPR dan konstituante. Setelah memasuki masa Orde Baru, pemilihan umum tetap dilaksanakan sebagai sarana untuk memilih wakil-wakil rakyat yang akan duduk sebagai anggota DPR dan MPR. Sepanjang enam kali penyelenggaraan pemilu pada masa Orde Baru, pemilu sekadar bersifat seremoni dan prosedural. Berbagai cara dilakukan oleh partai dari pemerintah yang berkuasa agar memenangkan pemilu. Selepas berakhirnya Orde Baru, Indonesia melaksanakan pemilu pertama kali pada 1999, dan diikuti oleh 48 partai. Kendati demikian, hanya 21 partai yang berhasil lolos dan memperoleh kesempatan menempatkan wakil-wakilnya di parlemen (Hakim, 2018).

Berbeda dengan sistem sebelumnya yang menggunakan sistem pemilihan presiden dan wakil presiden oleh anggota parlemen, pada pemilu 2004, pemilihan presiden dan wakil presiden dilakukan secara langsung. Sistem demikian masih dipertahankan pada pemilu selanjutnya pada 2009. Pada 2014, diberlakukan kebijakan baru berdasarkan aturan parliamentary threshold, yang memberlakukan hasil pemilihan legislatif sebelumnya sebagai dasar penentuan lolos tidaknya partai peserta pemilu. Beberapa partai yang tidak memenuhi syarat parliamentary threshold kemudian berganti nama untuk mengikuti pemilu 2019. Selain itu, pemilu 2014 juga memberlakukan sistem baru, yaitu sistem proporsional terbuka. Ini dilakukan untuk membuka partisipasi pemilih yang diharapkan meningkat. Caleg peraih suara terbanyaklah yang akan menduduki kursi di parlemen, dan bukan berdasar nomor urut. Dengan sistem ini, caleg yang dikenal masyarakat juga bisa mendongkrak popularitas partai.

Pada pemilu 2019, pemilihan anggota legislatif diselenggarakan bersamaan dengan pemilihan presiden dan wakil presiden, berbeda dengan pemilu 2014 yang dilaksanakan pada waktu yang berbeda. Pada 2014, pemilihan legislatif diselenggarakan pada 9 April, dan pemilihan presiden diadakan 3 bulan setelahnya pada 9 Juli 2014. Perbedaan penyelenggaraan teknis pemilu ini menyebabkan perbedaan dinamika politik yang terjadi di masyarakat dan berpengaruh pada pemberitaan media.

Selama pemilu 2019, pemanfaatan media massa daring (online) mengalami perkembangan hebat sehingga dinamika politik menjadi lebih terasa. Apalagi jika melihat pengguna internet di Indonesia. Berdasarkan data Kemenkominfo, yang telah mencapai 143 juta atau 54\% dari 265 juta penduduk (Hutabarat, 2018). Pengguna internet yang besar tersebut menjadikan media daring dimanfaatkan sebagai media pemberitaan untuk meraih popularitas bagi partai politik dan caleg yang berkompetisi pada pemilihan legislatif 2019. Popularitas tersebut dijadikan sebagai modal memperebutkan suara pemilih. Apalagi, pada pemilu 2019, ada peraturan baru parliamentary threshold sebesar 4\% yang dianggap memberatkan partai-partai kecil sehingga partai dan caleg berusaha keras untuk muncul di media massa dan dikenal masyarakat.

Pada pemilu 2019 yang dianggap sebagai tahun politik membuat para caleg dan politisi yang akan bertarung dalam pemilu, dan berlomba-lomba tampil di 
media sejak awal. Pada bulan JanuariFebruari, para calon anggota legislatif berlomba muncul ke media sebelum digelarnya pemilihan legislatif pada 17 April 2019.

Media daring banyak dimanfaatkan untuk menyosialisasikan partai dan caleg yang bertarung pada pemilihan legislatif karena mempunyai kekuatan daya jangkau yang lebih luas dibandingkan media massa tradisional. Ketika media daring telah menjelma sebagai bagian dari moda media massa, maka daya jangkaunya akan meluas. Fedler dalam hal ini mengatakan bahwa bahwa "the mass media are the instrument of mass communication because of their large audience, the media are enormously powerful" (Yulianita, 2004: 217). Kekuatan media massa terletak pada daya jangkaunya yang sangat luas sehingga Fedler juga menyatakan bahwa kekuatannya juga luar biasa.

Dengan potensi kekuatannya yang mampu menjangkau massa yang luas, media massa daring menjadi ajang pertarungan partai-partai politik dan calon-calon anggota legislatif untuk menyolisasikan diri dan partai untuk mendapatkan sebanyak-banyaknya pemilih pada pemilu 2019. Sementara itu, dengan potensi yang luar biasa, media seharusnya juga bisa berfungsi sebagai pemberi informasi dan pendidik yang baik untuk masyarakat. Menurut McQuail, media dapat menjadi kekuatan potensial untuk pencerahan publik, meningkatkan dan meneruskan institusi baru dari sekolah universal, perpustakaan publik, dan pendidikan popular. Secara umum, para pembaharu politik dan sosial melihat potensi positif media; sementara media juga memandang diri mereka sendiri telah membuat kontribusi bagi kemajuan dengan menyebarkan informasi dan ide, menyingkap korupsi politik dan menyediakan kesenangan yang tidak terlalu berbahaya bagi masyarakat pada umumnya (McQuail, 2011:59).

Mengutip pendapat Alexis S Tan, Nuruddin (2015: 65) menyebutkan bahwa fungsi komunikasi massa adalah memberi informasi, mendidik, mempersuasi, menyenangkan dan memuaskan kebutuhan komunikan. Fungsi mendidik ini dijelaskan sebagai memperoleh pengetahuan dan keterampilan yang berguna, memfungsikan dirinya secara efektif dalam masyarakatnya, mempelajari nilai, tingkah laku yang cocok agar diterima dalam masyarakatnya. Berdasarkan konsensus para ahli komunikasi, jelas bahwa media massa termasuk di dalamnya media daring seharusnya menjadi kekuatan potensial untuk pencerahan publik, menyebarkan informasi dan ide.

Media massa sendiri kini tidak bisa dilepaskan dari politik. Pemberitaan yang muncul di media massa dan iklan yang ditayangkan ditujukan untuk mempengaruhi pilihan dan preferensi politik khalayaknya. Dalam komunikasi politik, kandidat dijadikan sebagai produk yang akan dijual. Media massa termasuk di dalamnya media daring digunakan untuk membentuk citra bagi calon anggota legislatif dan partai yang akan bertarung. Citra seorang tokoh politik sangatlah penting, seperti didisebutkan Sumbo Tinarbuko. Menurut Yasraf Amir Piliang dalam politik informasi, citra politik seorang tokoh yang dibangun melalui aneka media cetak dan elektronik terlepas dari kecakapan, kepemimpinan dan prestasi politik yang dimilikinyaseakan menjadi mantra yang menentukan pilihan politik. Melalui mantra elektronik itu, persepsi, pandangan dan sikap politik masyarakat dibentuk bahkan dimanipulasi. Politik kini menjelma menjadi politik pencitraan, yang merayakan citra ketimbang kompetensi politik - the politics of image (Tinarbuko, 2009:vii). 
Sementara itu, Straubhaar, LaRose \& Davenport (2012:433) menyatakan "the campaign coverage that appears in the media, including news stories, opinion polls, public appearances by the candidates, debates, and editorial edorsements, is inherently more effective than political advertisements." Dari pendapat tersebut, dapat dipahami bahwa media dan politik tidak dapat dilepaskan begitu saja. Media telah menjadi alat efektif untuk mengangkat isu-isu politik dan calon anggota legislatif ketika masa pemilihan umum akan berlangsung. Apakah caranya dengan iklan politik atau dengan menggunakan pemberitaan dengan cara yang lain, media menjadi salah satu sarana efektif untuk mendapatkan massa pemilih. Bahkan, menurut Straubhaar, LaRose \& Davenport (2012;433), penampilan secara publik seorang kandidatpun bisa dinilai sebagai komunikasi politik dan termasuk dalam kegiatan kampanye efektif untuk meraih suara.

Dalam dunia politik, terutama pada pemilihan legislatif 2019, media massa banyak memuat pemberitaan bukan sebagai pemberi informasi dan pendidikan politik yang baik bagi masyarakat. Media cenderung lebih banyak memuat pernyataan-pernyataan atau pemberitaanpemberitaan peristiwa politik saja tanpa memperhatikan sentimen pemberitaan positif atau negatif, profil caleg dan partai, atau justru memberitakan masalah pribadi calon anggota legislatif. Sementara isu-isu yang berkaitan dengan daerah pemilihan sebagai pendidikan politik, seringkali, terlewatkan atau tidak ditampilkan sama sekali karena calon anggota-anggota legislatif ini lebih mengejar popularitas yang menjadi modal keterpilihan.

Untuk pemilu di Jakarta, wilayah tersebut merupakan arena pertarungan politik terbesar yang mendapatkan porsi pemberitaan media yang paling banyak. Selain banyak yang berkedudukan di kota tersebut, calon-calon legislatif yang bertarung di Daerah Pemilihan (Dapil) Jakarta umumnya juga merupakan kandidat yang telah populer dengan potensi pemberitaan yang besar. Banyak di antara calon anggota legislatif yang bertarung di Dapil Jakarta merupakan ketua partai, pejabat, dan pengurus partai yang sebelumnya sudah menjadi anggota legislatif dan ingin kembali menduduki jabatan yang sama. Pada umumnya, mereka telah mempunyai nilai pemberitaan bagi media sehingga coverage pemberitaan media bagi mereka juga peluangnya lebih besar. Namun, pemberitaan media tentang calon-calon anggota legislatif saat ini masih memiliki kecenderungan untuk menampilkan berita yang sifatnya tidak memberikan informasi dan pendidikan politik bagi khalayak. Di antara kecenderungan tersebut, misalnya, informasi mengenai Dapil yang akan mereka wakili ataupun informasi yang berkaitan dengan isu yang berkembang di masing-masing Dapil lebih menitikberatkan kepada pemberitaan yang dianggap dapat menarik perhatian khalayak, semacam perihal peristiwa politik secara umum, pilpres, atau masalah pribadi.

Saat ini, peran media massa sebagai sarana iklan politik partai merupakan sebuah kewajaran. Hasil penelitian yang dilakukan oleh Mustofa (2013), menyatakan bahwa dari segi pendidikan politik selama ini, kampanye media tak ubahnya ritual politik yang tak bermakna. Sejalan dengan pendapat tersebut, Nuryanti (2018) menyatakan bahwa dalam penyelenggaraan pemilu masyarakat lebih mengenal dan mengetahui partai politik proses dan mekanisme pemilu melalui media, meskipun media juga mempunyai kelemahan karena cenderung terkesan menyederhanakan, personalisasi, dan 
emosional. Dari proposisi tersebut, dipercaya bahwa media massa selama masa menjelang pemilu seringkali menjadi sarana iklan politik. Masyarakat pada umumnya mengetahui mengenai peristiwa politik, proses pemilu, caleg dan isu yang mereka hadapi di Dapil dari media meskipun media cenderung menyederhanakan, mempersonalisasi, dan emosional.

Sebagai wilayah dengan tingkat kompetisi maupun partai politik yang tinggi dibandingkan daerah lain, pemilu di Jakarta tentu memperoleh ruang paparan yang lebih banyak dalam konteks pemberitaan media daring. Memasuki 2019, dalam kacamata pemantauan atau penelitian media, menjadi menarik untuk memperlihatkan bagaimanakah pemberitaan caleg di kota tersebut. Selain itu, perlu pula dipertanyakan bagaimana kecenderungan pemberitaan media daring, apakah menjadi media komunikasi pemasaran politik tanpa melihat fungsi pendidikan yang seharusnya ada pada media massa, atau mereka mampu menjadi sarana pendidikan politik bagi masyarakat?

\section{Metode Penelitian}

Penelitian ini dilakukan dengan metode media content analysis. Rachmat Kriyantono menyebutkan bahwa menurut Berelson \& Kerlinger, analisis isi merupakan suatu metode untuk mempelajari dan menganalisis komunikasi secara sistematik, obyektif, dan kuantitatif terhadap pesan yang tampak (Kriyantono, 2010:233)

Deskripsi lain mengenai tujuan analisis isi disampaikan oleh Wimmer dan Dominick dalam Kriyantono (2010:234), yakni untuk: (1) Menggambarkan isi komunikasi; (2) Menguji hipotesis tentang karakteristik pesan; (3) Membandingkan isi media dengan dunia nyata; (4) Memperkirakan gambaran media terhadap kelompok tertentu di masyarakat; dan (5) Mendukung studi efek media massa.

Analisis paling dasar dalam analisis isi media ini dengan mengkategorikan pemberitaan apakah bemuatan pemberitaan positif atau negatif atau netral. Dalam analisis isi, metode pengumpulan datanya adalah mendokumentasi isi komunikasi, dan kemudian memasukkan data dalam kategorisasi yang ditentukan dengan menggunakan lembar koding. Pada penelitian ini, yang dilihat adalah jumlah pemberitaan pada masing-masing Dapil, sentimen pemberitaan, subjek pemberitaan, keterkaitan isi berita dengan permasalahan Dapil, signifikansi masalah yang dibahas pada pemberitaan dengan permasalahan Dapil, jumlah partai yang mendapatkan pemberitaan media online, dan permasalahan yang muncul dalam pemberitaan media online pada periode waktu Januari sampai Februari 2019.

\section{Hasil dan Pembahasan}

DKI Jakarta merupakan arena persaingan terketat untuk para calon anggota legislatif DPR Pusat. Banyak nama yang sudah terkenal dan mempunyai modal politik kuat bersaing di Jakarta. DKI Jakarta sendiri dibagi menjadi 3 Dapil, yaitu sebagai berikut.

1. Dapil I, meliputi Jakarta Timur dengan porsi 6 kursi.

2. Dapil II, meliputi Jakarta Pusat + luar negeri dan Jakarta Selatan dengan porsi 7 kursi.

3. Dapil III, meliputi Kepulauan Seribu, Jakarta Utara dan Jakarta barat dengan porsi 8 kursi.

Untuk periode bulan Januari 2019, pemberitaan mengenai caleg dari Dapil I, II, dan III Jakarta, total terdapat 104 pemberitaan dari berbagai media daring. Dari 104 pemberitaan, sentimen 
pemberitaan tentang caleg adalah sebagai berikut. Jumlah pemberitaan media daring untuk Dapil I, II, III DKI Jakarta, paling banyak ditempati oleh Dapil I sebanyak 48 berita (46,15 \%), pemberitaan paling banyak kedua oleh Dapil III sebanyak 35 berita (33,65 \%) dan paling sedikit di Dapil II sebanyak 21 berita (33,65 \%).

Tabel 1. Sebaran pemberitaan media daring Pileg DKI Jakarta Januari 2019

\begin{tabular}{lcc}
\hline \multicolumn{1}{c}{ Label } & Frekuensi & Persentase \\
\hline Jakarta I & 48 & 46,15 \\
Jakarta II & 21 & 20,19 \\
Jakarta III & 35 & 33,65 \\
Total & 104 & 100,0 \\
\hline
\end{tabular}

Pemberitaan bersentimen positif berjumlah 26 berita (25\%), pemberitaan dengan sentimen negatif berjumlah 42 berita (40, 38\%) dan pemberitaan dengan sentimen netral berjumlah 36 berita $(34,62 \%)$. Dari hasil tersebut dapat dilihat bahwa pemberitaan tentang caleg pada periode 1-30 Januari 2019 di Dapil I, II, dan III DKI Jakarta masih di dominasi oleh pemberitaan yang bersifat negatif. Pemberitaan dengan sentimen netral menempati urutan kedua dan pemberitaan yang bersentimen positif yang seharusnya ada di media daring justru menempati tempat ke-tiga dan menduduki jumlah paling kecil dengan 26 pemberitaan. Pemberitaan negatif pada periode ini karena banyak caleg yang mengomentari pemilihan presiden dan partai yang melaporkan pihak lain ke polisi maupun lembaga pengawas pemilu.

Tabel 2. Sentimen Pemberitaan Media Daring Januari 2019

\begin{tabular}{lcc}
\hline \multicolumn{1}{c}{ Label } & Frekuensi & Persentase \\
\hline Positif & 26 & 25,00 \\
Negatif & 42 & 40,38 \\
Netral & 36 & 34,62 \\
Total & 104 & 100,00 \\
\hline
\end{tabular}

Sementara untuk subjek pemberitaan, lebih banyak pemberitaan yang memberitakan caleg daripada partai dengan subjek pemberitaan partai sebanyak 25 berita (24, 04\%), sementara berita dengan subjek pemberitaan caleg sebanyak 79 berita $(75,96 \%)$. 
Tabel 3. Subjek Pemberitaan Media Daring Januari 2019

\begin{tabular}{lcc}
\hline \multicolumn{1}{c}{ Label } & Frekuensi & Persentase \\
\hline Partai & 25 & 24,04 \\
Caleg & 79 & 75,96 \\
Total & 104 & 100,00 \\
\hline
\end{tabular}

Untuk isu yang diangkat dalam pemberitaan mengenai caleg apakah terkait dengan Dapil atau tidak, selama bulan Januari 2019 ternyata lebih banyak pemberitaan yang isunya tidak berkaitan sama sekali dengan Dapil. Perbandingan pemberitaan dengan isu yang berkaitan dengan Dapil dan tidak adalah pemberitaan yang berkaitan dengan Dapil sebanyak 4 pemberitaan $(3,85 \%)$ sementara pemberitaan yang tidak berkaitan dengan Dapil sebanyak 100 pemberitaan ( 96,15 pemberitaan).

Tabel 4. Keterkaitan Pemberitaan Caleg dengan Dapil Januari 2019

\begin{tabular}{lcc}
\hline \multicolumn{1}{c}{ Label } & Frekuensi & Persentase \\
\hline Terkait & 4 & 3,85 \\
Tidak terkait & 100 & 96,15 \\
Total & 104 & 100,00 \\
\hline
\end{tabular}

Sementara isu yang diangkat dalam pemberitaan apakah signifikan dengan isu yang ada di Dapil bisa dilihat bahwa isu yang terangkat dalam pemberitaan caleg DKI selama Januari 2019 tidak signifikan dengan Dapil yang akan mereka wakili.
Perbandingannya adalah pemberitaan yang signifikan dengan isu Dapil hanya 4 pemberitaan $(3,85 \%)$ sementara yang tidak berkaitan jauh lebih besar sebanyak 100 pemberitaan $(96,15 \%)$.

Tabel 5. Siginifikansi Isu Pemberitaan dengan Dapil pada Januari 2019

\begin{tabular}{lcc}
\hline \multicolumn{1}{c}{ Label } & Frekuensi & Persentase \\
\hline Signifikan & 4 & 3,85 \\
Tidak & 100 & 96,15 \\
signifikan & & \\
TOTAL & 104 & 100,00 \\
\hline
\end{tabular}

Sementara untuk isu atau topik pemberitaan yang ter-cover oleh pemberitaan media daring selama Januari paling banyak adalah pemberitaan mengenai peristiwa politik sebanyak 79 berita $(75,96 \%)$ sementara mengenai profil caleg atau partai politik sebanyak 15 berita (14,42 \%), dan pemberitaan mengenai persoalan pribadi sebanyak 10 pemberitaan (9,62 \%). 
Tabel 6. Topik Pemberitaan Media Daring Januari 2019

\begin{tabular}{lcc}
\hline \multicolumn{1}{c}{ Label } & Frekuensi & Persentase \\
\hline Peristiwa politik & 79 & 75,96 \\
Profil caleg / partai politik & 15 & 14,42 \\
Masalah pribadi & 10 & 9,62 \\
TOTAL & 104 & 100,00 \\
\hline
\end{tabular}

Untuk asal partai dari caleg yang mendapatkan pemberitaan paling banyak di bulan Januari 2019 adalah PSI dengan 26 pemberitaan (25\%) dan yang paling sedikit adalah Nasdem dengan 2 pemberitaan (1,92 \%). Selain itu, juga bisa dilihat bahwa partai yang mendapatkan sorotan pemberitaan tetap partai-partai lama yang sudah mempunyai posisi kecuali PSI yang merupakan partai baru.

Tabel 7. Asal Partai Caleg dalam Pemberitaan Media Daring Januari 2019

\begin{tabular}{lcc}
\hline \multicolumn{1}{c}{ Label } & Frekuensi & Persentase \\
\hline PSI & 26 & 25,00 \\
PDIP & 17 & 16,35 \\
Gerindra & 10 & 9,62 \\
Nasdem & 2 & 1,92 \\
PKS & 10 & 9,62 \\
PKB & 8 & 7,69 \\
PAN & 14 & 13,46 \\
PBB & 17 & 16,35 \\
TOTAL & 104 & 100,00 \\
\hline
\end{tabular}

Sementara untuk periode bulan Februari 2019, total jumlah pemberitaan media online mengenai caleg di Dapil I, II, dan III DKI berjumlah 179 pemberitaan. Pemberitaan paling banyak ada di Dapil
DKI II dengan 99 pemberitaan (55,31\%), kemudian disusul oleh DKI III dengan 49 pemberitaan (27,37\%) dan kemudian baru DKI Idengan 31 pemberitaan (27,37\%).

Tabel 8. Pemberitaan Media Online Perihal Caleg Februari 2019

\begin{tabular}{lcc}
\hline \multicolumn{1}{c}{ Label } & Frekuensi & Persentase \\
\hline Jakarta I & 31 & 17,32 \\
Jakarta II & 99 & 55,31 \\
Jakarta III & 49 & 27,37 \\
TOTAL & 179 & 100,0 \\
\hline
\end{tabular}


Dari total 179 pemberitaan pada periode Februari 2019, sentimen pemberitaan tentang caleg di Dapil DKI Jakarta lebih bersentimen positif berbeda dengan pemberitaan untuk periode bulan Januari, meskipun perbedaan antara sentimen positif, negatif, dan netral perbedaannya tidak terlalu jauh. Untuk pemberitaan bersentimen positif sebanyak 67 pemberitaan $(37,43 \%)$, pemberitaan negatif sebanyak 58 pemberitaan $(32,40$ $\%)$, dan pemberitaan dengan sentimen netral sebanyak 54 pemberitaan (30,17\%).

Tabel 9. Sentimen Pemberitaan Media Daring Februari 2019

\begin{tabular}{lcc}
\hline \multicolumn{1}{c}{ Label } & Frekuensi & Persentase \\
\hline Positif & 67 & 37,43 \\
Negatif & 58 & 32,40 \\
Netral & 54 & 30,17 \\
TOTAL & 179 & 100,00 \\
\hline
\end{tabular}

Sementara untuk subjek pemberitaan antara caleg atau partai, pemberitaan di bulan Februari 2019 masih sama dengan pemberitaan di bulan Januari di mana pemberitaan mengenai caleg lebih banyak dibanding pemberitaan mengenai partai dengan perbandingan pemberitaan mengenai partai sebanyak 43 pemberitaan (24,02 \%) dan pemberitaan mengenai caleg sebanyak 136 pemberitaan $(75,98 \%)$

Tabel 10. Subjek Pemberitaan Media Daring Februari 2019

\begin{tabular}{lcc}
\hline \multicolumn{1}{c}{ Label } & Frekuensi & Persentase \\
\hline Partai & 43 & 24,02 \\
Caleg & 136 & 75,98 \\
TOTAL & 179 & 100,00 \\
\hline
\end{tabular}

Untuk keterkaitan isu pemberitaan dengan Dapil, bisa diketahui bahwa pemberitaan mengenai isu-isu Dapil tetap tidak banyak terekspos. Perbandingan pemberitaan mengenai isu Dapil dan isu bukan Dapil adalah pemberitaan mengenai Dapil sebanyak 38 pemberitaan (21,23 \%) sementara pemberitaan yang tidak berkaitan dengan Dapil sebanyak 141 pemberitaan $(78,77 \%)$.

Tabel 11. Keterkaitan Pemberitaan Caleg dengan Dapil Februari 2019

\begin{tabular}{lcc}
\hline \multicolumn{1}{c}{ Label } & Frekuensi & Persentase \\
\hline Terkait & 38 & $\mathbf{2 1 , 2 3}$ \\
Tidak terkait & 141 & 78,77 \\
TOTAL & 179 & 100,00 \\
\hline
\end{tabular}


Soal signifikansi isu yang diberitakan apakah signifikan dengan kepentingan atau isu Dapil bisa dilihat bahwa pemberitaan yang signifikan dengan Dapil hanya 8 pemberitaan $(4,47$ \%) sementara pemberitaan yang tidak siginifikan dengan Dapil sebanyak 171 pemberitaan $(95,53) \%$.

Tabel 12. Siginifikansi Isu Pemberitaan dengan Dapil pada Februari 2019

\begin{tabular}{lcc}
\hline \multicolumn{1}{c}{ Label } & Frekuensi & Persentase \\
\hline Signifikan & 8 & 4,47 \\
Tidak Signifikan & 171 & 95,53 \\
TOTAL & 179 & 100,00 \\
\hline
\end{tabular}

Untuk isu yang terekspos pada pemberitaan media daring selama bulan Februari 2019, mempunyai komposisi yang hampir sama dengan periode bulan Januari di mana pemberitaan paling banyak adalah peristiwa politik sebanyak
146 pemberitaan $(81,57 \%)$ kemudian disusul dengan profil caleg atau partai politik sebanyak 23 berita (12.85\%) dan disusul dengan masalah pribadi sebanyak 10 berita $(5,59 \%)$.

Tabel. 13. Topik Pemberitaan Media Daring Februari 2019

\begin{tabular}{lcc}
\hline Label & Frekuensi & Persentase \\
\hline Peristiwa politik & 146 & 81,57 \\
Profil caleg / partai politik & 23 & 12,85 \\
Masalah pribadi & 10 & 5,59 \\
TOTAL & 179 & 100,0 \\
\hline
\end{tabular}

Sementara untuk partai asal caleg yang mendapat porsi pemberitaan paling banyak di Dapil DKI adalah PSI dengan 67 pemberitaan (37,43\%) dan yang paling kecil adalah Gerindra dengan 1 pemberitaan (0,56 \%). Untuk bulan
Februari, bahkan ada partai-partai yang pada bulan Januari mendapatkan pemberitaan, tetapi di bulan Februari sama sekali tidak mendapatkan pemberitaan melalui calegnya seperti Nasdem dan PKB.

Tabel 14. Asal Partai Caleg dalam Pemberitaan Media Daring Februari 2019

\begin{tabular}{lcc}
\hline \multicolumn{1}{c}{ Label } & Frekuensi & Persentase \\
\hline PSI & 67 & 37,43 \\
PDIP & 16 & 8,94 \\
Gerindra & 1 & 0,56 \\
PKS & 6 & 25,14 \\
PAN & 10 & 24,58 \\
PBB & 13 & 3,35 \\
TOTAL & 179 & 100,00 \\
\hline
\end{tabular}


Jika dibandingkan dalam dua bulan monitoring, dapat dilihat hasilnya sebagai berikut. Dalam hal subjek berita, berita tentang caleg jauh lebih banyak dibanding berita tentang partai; dan untuk nilai pendidikan bagi warga yang didasarkan pada berita yang terkait dengan Dapil, dapat disimpulkan bahwa berita yang terkait dengan Dapil sangat sedikit. Demikian pula dengan berita yang siginifikan dengan isu Dapil juga sangat sedikit. Pemberitaan mengenai Dapil tersebut tertutup dengan pemberitaan tentang kampanye hitam yang dilakukan atau diterima oleh partai politik, masalah pilpres, dan masalah pribadi yang dihadapi oleh caleg, seperti misalnya PSI yang mendapatkan porsi pemberitaan besar dari kasus spanduk dukungan LGBT, caleg yang merupakan timses pemilihan presiden yang berkomentar negatif terhadap calon presiden lawan, dan masalah pribadi seperti caleg dan pejabat yang diperiksa oleh KPK. Sedangkan mengenai topik pemberitaan, isu terbanyak masih berkutat soal peristiwa politik secara umum, seperti masalah pilpres, profil partai dan caleg, atau caleg yang menanggapi kampanye pilpres. Pada sisi ini, hasil monitoring terhadap pemberitaan yang merupakan bagian dari pendidikan politik, yaitu mengenai isu-isu yang terkait dan signifikan dengan Dapil jumlahnya jauh lebih sedikit dibandingkan dengan jumlah pemberitaan yang sama sekali tidak berkaitan dan tidak signifikan sama sekali dengan Dapil.

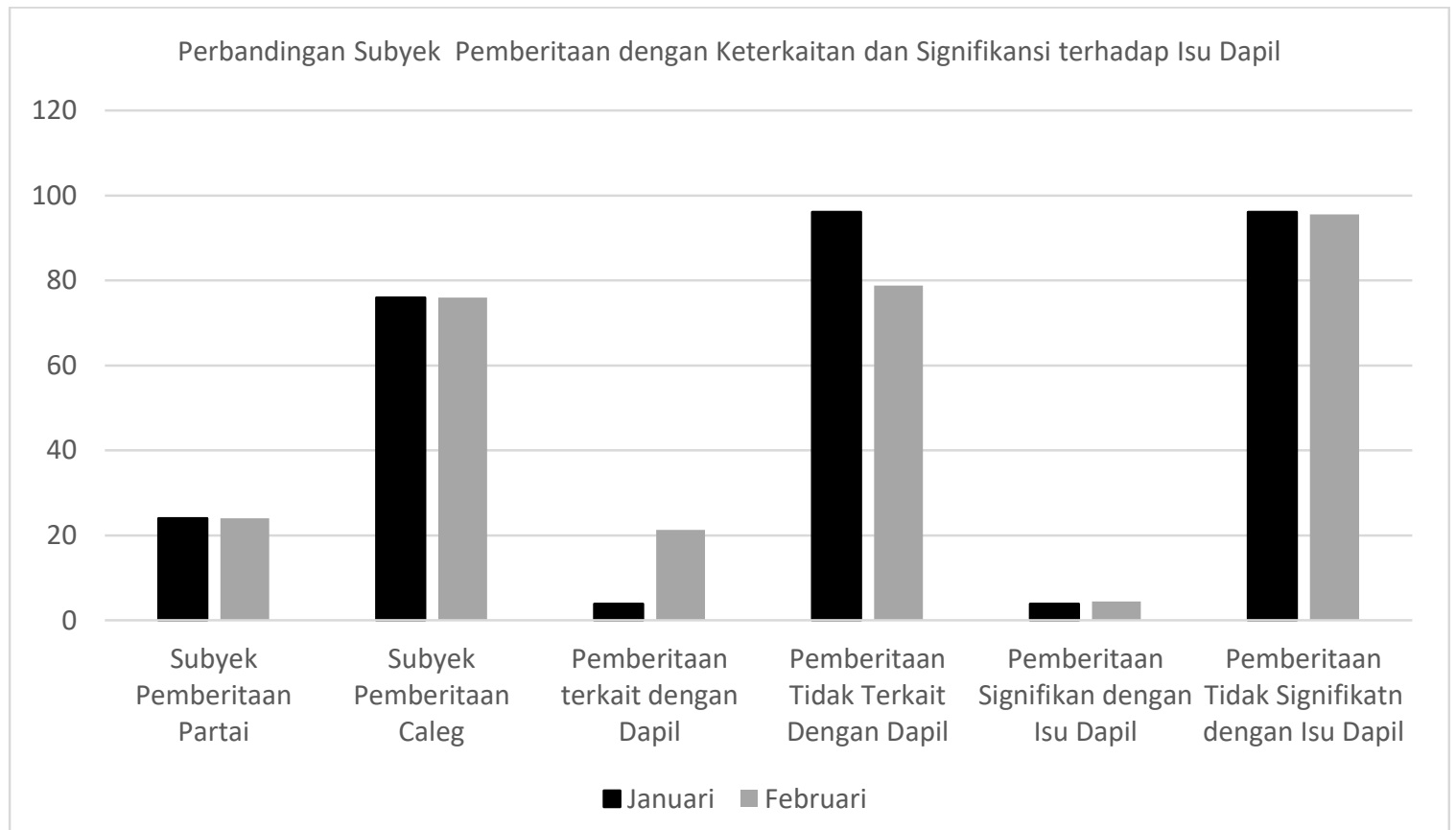

Grafik 1. Perbandingan subjek pemberitaan dengan keterkaitan berita dan signifikansi berita terhadap isu dapil Januari dan Februari 2019

Mengenai pemberitaan partai asal para caleg, ternyata partai yang sudah lama dan stabil tidak menjamin adanya peliputan media yang banyak untuk individu calegnya. Terbukti pada Nasdem dan PKB yang notabene merupakan partai lama, justru tidak mendapat pemberitaan pada bulan Februari; sementara PSI yang masih baru calegnya justru mendapat pemberitaan paling banyak. Banyaknya pemberitaan mengenai PSI ini dikarenakan PSI mempunyai tokoh-tokoh yang sering mengeluarkan pernyataan 
kontroversial sehingga mampu menyedot pemberitaan.

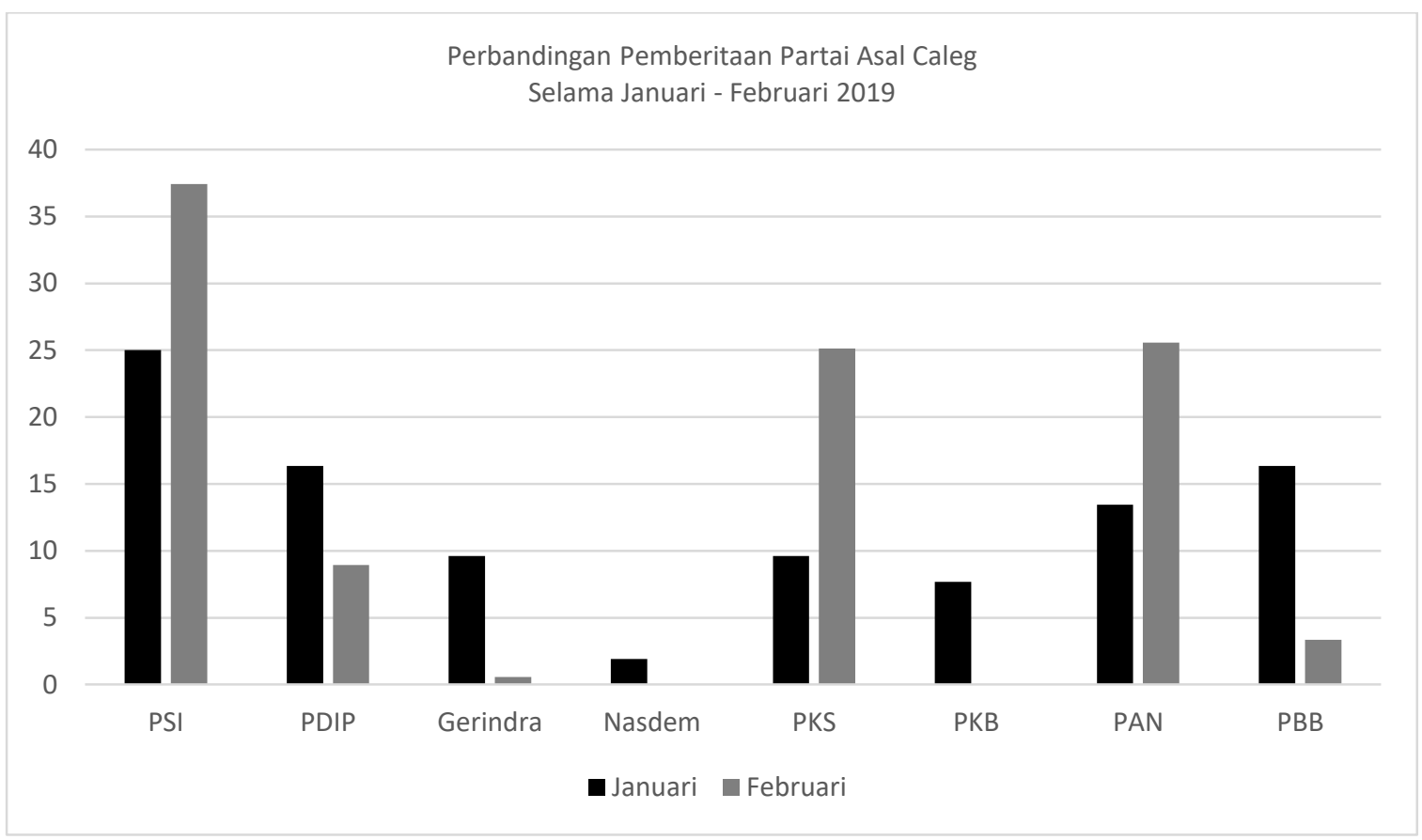

Grafik 2. Perbandingan pemberitaan mengenai partai asal Caleg selama Januari dan Februari 2019

Berdasarkan grafik 2, dapat disimpulkan bahwa selama DKI selama Januari- Februari 2019, media daring belum dapat menjadi sarana pendidikan politik bagi masyarakat dan penyebar isu positif politik. Pemberitaan yang muncul bukanlah pemberitaan yang berisi isu Dapil dan tidak memiliki kaitannya dengan Dapil. Pemberitaan lebih banyak mengekspos peristiwa politik secara umum, perselisihan, atau justru masalah pribadi caleg yang memperebutkan kursi. Dalam kaitan ini, media masih belum maksimal dalam memainkan perannya sebagai sarana pendidikan politik dan masih banyak memuat konten yang akan menarik perhatian masyarakat tanpa memperhatikan kebutuhan informasi masyarakat.

\section{Kesimpulan}

Berdasarkan hasil media monitoring selama bulan Januari hingga Februari 2019, dapat disimpulkan bahwa pemberitaan bulan Februari lebih banyak dibandingkan pemberitaan pada bulan Januari. Kendati demikian, pemberitaan bulan Januari mempunyai sentimen negatif yang lebih banyak dibanding bulan Februari. Pemberitaan dengan sentimen negatif tersebut merupakan pemberitaan yang mengandung perselisihan atau caleg dan partai yang mendapat kampanye negatif, ataupun mengandung pernyataan kontroversial.

Sementara secara isi, pemberitaan lebih banyak menampilkan peristiwa politik secara umum, bukan pemberitaan yang mengarah kepada partai atau caleg, atau justru pemberitaan mengenai masalah pribadi, sehingga sebetulnya kurang efektif sebagai media pengenalan 
partai dan caleg, dan sebagai informasi dan pembelajaran yang positif tentang politik bagi masyarakat.

Riset ini memang hanya mengidentifikasi secara tersurat pesan yang hadir dalam pemberitaan sesuai karakteristik analisis isi. Namun, masalah analisis isi bahwa ia tidak mampu mencek apakah pemberitaan yang teridentifikasi di atas mempunyai pengaruh pada khalayak. Oleh karena itu, riset-riset yang menggabungkan analisis isi dan khalayak sangat penting untuk mengetahui karakteristik teks yang dihubungkan dengan dampak-dampaknya. Riset semacam ini penting terutama karena tujuan-tujuan pajanan pesan politik adalah demi mempengaruhi pemilih. Riset-riset semacam ini juga akan memberikan partai politik referensi yang relatif memadai untuk membangun strategis kampanye yang efektif.

\section{Daftar Pustaka}

Davenport, LaRose, Straubhaar. 2012. Media Now, Boston: Cengage Learning.

Hakim, Rakhmat Nur .2018. "Partai Politik yang Bertarung di Pemilu dari Masa ke Masa", terarsip di https://nasional.kompas.com/read/ 2018/02/20/13275281/partaipolitik-yang-bertarung-di-pemiludari-masa-ke-masa. Kompas.com., 20 Februari 2018.

Hutabarat Diani. 2018. "Kementerian Kominfo Sebut Pengguna Internet Indonesia Capai 54 \%” terarsip di https://kominfo.go.id/content/detai l/15380/kementerian-kominfosebutpenggunainternet-indonesiacapai-54-\%/o/sorotan_media, 19 November 2018.

Kriyantono, Rachmat. 2010. "Teknik Praktis Riset Komunikasi” (Cetakan ke-5). Jakarta: Kencana Prenada Media Group

McQuail, Dennis. 2011. Teori Komunikasi Massa (Buku 1 edisi 6). Jakarta: Salemba Humanika.
Mustofa, Ali. 2013. "Peran Media Massa sebagai Sarana Iklan Politik Parpol (Kajian Terhadap Kasus Surya Paloh dan Partai Nasdem)," dalam Interaksi: Jurnal Ilmu Komunikasi, vol. 2, no. 1, pp. 62-69, Jan. 2013. https://doi.org/10.14710/interaksi.2 .1.62-69.

Nurudin. 2015. Pengantar Komunikasi Massa. Jakarta: PT Raja Grafindo Persada.

Nuryanti. 2018. Peranan Media Massa dalam Pemilihan Umum di Indonesia, https://journal.unnes.ac.id/sju/inde x.php/snh

Tinarbuko, Sumbo. 2009. Iklan Politik dalam Realitas dan Media. Yogyakarta: Jalasutra.

Yulianita, Neni. 2004. Media Massa: Strategi Politik dalam Menghadapi Pemilu,. https://ejournal.unisba.ac.id/index.php/ mediator/article/view/858/pdf 
Jurnal komunikasi, Volume 13, Nomor 2, April 2019, Hal 165-178 